\title{
HOW
}

Volume 28, Number 3, pages 31 - 46

https://doi.org/10.19183/how.28.3.685

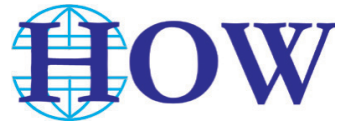

\section{Publishing in Local ELT Journals: \\ A Way to Decolonialize Knowledge}

\author{
Publicar en Revistas Locales de Enseñanza del Inglés: \\ Una Forma de Descolonizar el Conocimiento
}

\section{Melba Libia Cárdenas ${ }^{1}$}

\begin{abstract}
Educational institutions, particularly those for higher education, seek to ensure their visibility and valid indicators for institutional accreditation processes through the publications of their teachers. Their projection is intimately associated with the circulation of their production in accredited publications whose reputations depend on their positions in prestigious rankings, databases, and indexing systems. That is why Colombia, in recent years, has experienced an increase in the number of scientific journals published in the country. This phenomenon was a reaction by academics to the obstacles for publishing in renowned journals, generally edited in hegemonic or central contexts, where it is presumed that knowledge is disseminated for the whole world. In this article, I analyze the role played by locally edited journals in the decolonialization of knowledge. I base my analysis on studies carried out in the fields of the English teacher as researcher and writer, academic writings, and the publication of scientific journals. I identify the contributions, suggestions and challenges for publications in the English Language Teaching area. I also stress the importance of strengthening professional communities, encouraging greater participation by professors in the dissemination of their work, and the need to value knowledge generated in peripheral contexts, without ignoring links with the global world.
\end{abstract}

Keywords: academic writing, decolonializing knowledge, ELT journals, publishing, scientific journals

She is an associate professor of the Foreign Languages Department at Universidad Nacional de Colombia. She holds an M.A. in TESOL-Teacher Education (University of Edinburgh) and is a Ph.D. Candidate in Education (Universidad de Zaragoza, Spain). She belongs to the PROFILE and LEXI research groups and edits the Profile journal.

mlcardenasb@unal.edu.co

ORCID ID: https://orcid.org/0000-0003-0028-2506

Received: September 7th, 2021. Accepted: September 19th, 2021.

This article is licensed under a Creative Commons Attribution-Non-Commercial-No-Derivatives 4.0 International License. License Deed can be consulted at https://creativecommons.org/licenses/by-nc-nd/4.0. 


\section{Melba Libia Cárdenas}

\section{Resumen}

Las instituciones educativas, principalmente de educación superior, buscan asegurar su visibilidad e indicadores válidos para los procesos de acreditación institucional mediante las publicaciones de sus docentes. Su proyección está íntimamente asociada a la circulación de su producción en publicaciones acreditadas, cuya reputación depende de su ubicación en prestigiosos ránquines, bases de datos y sistemas de indexación. Por ello, Colombia vivió en los últimos años un incremento en el número de revistas científicas editadas en el país. El fenómeno fue una reacción de los académicos frente a los obstáculos para publicar en revistas de renombre, editadas generalmente en contextos hegemónicos o de centro donde se presume se divulga conocimiento pertinente para todo el mundo. En este artículo analizo el papel que juegan las revistas editadas localmente en la descolonización del conocimiento. Para ello me baso en estudios realizados en los campos del docente de inglés como investigador y escritor, la escritura académica y la publicación de revistas científicas. Identifico los aportes, sugerencias y retos para las publicaciones del área de la enseñanza del inglés. Asimismo, destaco la importancia de fortalecer las comunidades profesionales, motivar una mayor participación de los docentes en la difusión de sus trabajos y la necesidad de valorar el conocimiento que se genera en contextos periféricos, sin desconocer los nexos con el mundo global.

Palabras clave: descolonización del conocimiento, escritura académica, publicación, revistas científicas, revistas de ELT

\section{Introduction}

The recognition of journals published in the West, viewed as "leading", "prestigious" and "elite", makes us frequently ask: Why should we ${ }^{2}$ publish in local journals? What for? In the past three decades, an important number of journals have been consolidated in Colombia. Some of them focus on foreign languages and related subjects and others involve questions of education. The rise and consolidation of scientific journals about English Language Teaching (ELT) in Colombia is associated with the integration of the research component from initial teacher education; greater involvement by teachers in applied research and in national and international academic events; and their interest in disseminating their work (Cárdenas, 2014, 2016). With the aim of achieving this last purpose, there is ever greater participation in writing articles for publication in journals, preferably in those indexed nationally or internationally.

32 In the most recent classification of journals published in the country (Minciencias, 2020), 277 such journals were indexed. One-hundred twenty-eight correspond to the field of social sciences and 52 to the humanities. Within the social sciences, eleven are in the field of education sciences and within the larger field of humanities, eight are in languages and literature. Four specialized journals are in the areas of ELT and Teaching English to

Note that "we" has been used in the manuscript as part of its stylistic choice: we, inclusive, to involve the reader. 
Speakers of Other Languages (TESOL) published exclusively in the English language: HOW (created in 1969 and led by the Colombian Association of Teachers of English (Asociación Colombiana de Profesores de Inglés - ASOCOPI), Profile (created in 2000 and published by the Universidad Nacional de Colombia), GIST Education and Learning Research Journal (founded in 2007, at the Institución Universitaria Colombo Americana - ÚNICA) and Latin American Journal of Content \& Language Integrated Learning - LACLIL (created in 2008, by the Universidad de La Sabana). Other journals address topics more broadly associated with education, languages and cultures, and applied linguistics. These are: Lenguaje (founded in 1972, at the Universidad del Valle), Folios (published since 1990 by the Universidad Pedagógica Nacional), Íkala (created in 1996, at the Universidad de Antioquia), Educación y Educadores (published since 1997 by the Universidad de La Sabana) and Colombian Applied Linguistics (created in 1999, at the Universidad Distrital Francisco José de Caldas).

On the other hand, journals have been created to encourage research and publication among undergraduate and postgraduate students of writings stemming from subjects they study or from their graduation projects. Particularly outstanding have been efforts to encourage writing and dissemination in local communities by Enletawa Journal (created in 2009, at the Universidad Pedagógica y Tecnológica de Colombia) and Opening Writing Doors Journal (published between 2002 and 2015).

We note that publications for teacher educators and language teachers have gradually multiplied in Colombia, not only due to their participation in research projects, but because the institutions are interested in leading processes for research or innovation and knowledge sharing. They also place greater importance on their faculty members making their production visible in national and international journals. Additionally, in many scenarios, the pressure exercised by governmental science and technology policies is much more evident in their attempts to have productions by academics become contributions to the productivity and visibility of both the country and its educational institutions. This is a signal of the "publish or perish" phenomenon, which refers to the pressure in the academic world for professors to publish rapidly and in a sustained manner to maintain their professional careers or advance in them. In this regard, Hicks, Wouters, Waltman, de Rijcke, and Rafols (2015) make the following historical summary:

Prior to 2000, experts used the Science Citation Index of the Institute for Scientific Information (ISI), in its CD-ROM version, to make specialized analyses. In 2002, Thomson Reuters launched an integrated web platform that extensively made the Web of Science database accessible to a wide-ranging public. Other indexes of citations then appeared to compete with Web of Science: Scopus Elsevier (2004) and Google Academico (beta version created in 2004). Web-based instruments were later introduced, such as InCites (which uses Web of Science) and SciVal (which uses Scopus) along with software to analyze individual profiles of citations based on Google Scholar (Publish or Perish, which appeared in 2007). (p. 275) 
In Colombia, governmental policies for evaluating journals have generated tensions because scholars question ethical, utilitarian, and mercantilist implications of the parameters of citation that, to a great extent, determine the classification and visibility of publications as greater or lesser contributors to scientific progress (Cárdenas \& Nieto, 2017, 2018a, 2018b; Leon-Sarmiento, Bayona-Prieto, Bayona, \& León, 2005; Londoño, 2006). Equally, there is resentment over pressures to increase the exogamy of authors that publish in journals along with the idiomatic barriers, because greater preponderance is given to English-language publications; above all, those published outside of the institution where teachers work and, preferably, in countries of the center.

From the perspective of the global economy, we use the term "periphery" to refer to countries such as Colombia, in contrast to "the center" (the hegemonic territory). The center is usually used to refer to Western English-speaking countries with strong economies (Cárdenas \& Rainey, 2018), which disseminate knowledge in the English language.

Paradoxically, the fact that a journal publishes in English does not guarantee greater appraisal or easier access to the above-mentioned bases and international indexing systems. Publishing in English is also a challenge for teachers from the field of ELT, which is why there is recognition of the need to examine the circumstances associated with that. Considering that we generally start to show our work in local scientific journals, we propose to examine their role in the dissemination of the work of teachers in professional and academic communities, along with encouragement of the recognition of their contributions towards knowledge in the field of ELT.

\section{Towards the Decolonization of Knowledge: Theoretical and Methodological Perspectives}

Colombian journals arise and evolve within a period of Latin American initiatives to consolidate publications as venues to encourage dissemination of the knowledge of nationals, along with authors from diverse latitudes: from both the periphery and from the center. The principles that motivate their creation and continuity are associated with the ideology of decolonization of knowledge that traditionally has conceded superiority and privileges to the theories and approaches of the center, thus perpetuating the status quo of scientific journals published in the West, with long-standing tradition and scarce diversity in the geographical location of their authors.

Local journals, as spaces for the dissemination of diverse types of knowledge (research products, reflections, and pedagogical experiences, among others), constitute ways to counteract the limitations that we teachers have for publishing in scientific journals of the center. This has been clear in the review of literature, in studies made in the framework of 
teacher professional development programs and in my own publishing work. Regarding the latter reference framework, it is important to mention that the proposals presented in this article also stem from my experiences as creator and editor of the journal Profile, as well as my participation as guest editor of the journal $\mathrm{HOW}^{3}$.

As shown in Figure 1, to advance in the decolonization of knowledge through local journals requires people who contribute to them (teachers as researchers and writers) and who have skills in academic writing. The journals, as means of knowledge dissemination, not only facilitate publication of their manuscripts, but also make them visible in the academic and professional communities. Additionally, in their editorial work, the journals examine the policies that govern their evaluation and decide which profiles of writings and authors can be published in them.

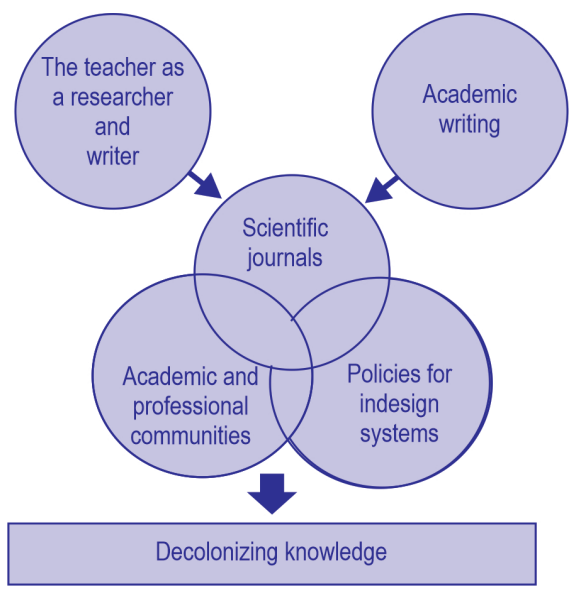

Figure 1. Fundamental axes for decolonization of knowledge through local journals

\section{The Scientific Journals}

Scientific journals, also referred to as specialized, scientific, or serialized scientific publications, are defined as periodical publications that seek to gather scientific progress through the dissemination of new research, innovations, scientific and technical information, and lines of thinking in a particular discipline or area of knowledge. These journals "traditionally constitute the main means for communication and conservation of scientific

I was the editor of HOW in 2004 and again from 2006 to 2018. The journal received support through the experience of Profile, which enabled it to incorporate international editorial standards and achieve indexation. 


\section{Melba Libia Cárdenas}

progress - considered in a broad sense: the pure and natural sciences as well as the social sciences and humanities" (Patalano, 2005, p. 217). They are also a way of contributing "to consolidate communities of specialists around specific topics, make it possible to generate bibliometric indicators about the positioning that in a particular time period an entity for dissemination within the academic community that it serves may achieve" (Aguado-López \& Rogel-Salazar, 2009, p. iv). In line with Ramírez Martínez, Martínez Ruiz, \& Castellanos Domínguez (2012), journals can also be understood as "a reflection of the general functioning of the sciences, other institutions, their researchers, and the relationship that each discipline has with itself, with other disciplines, and with society" (Colciencias, 2016, p. 1).

Scientific journals essentially seek to disseminate knowledge and to reach determined audiences through different means (print, digital or combined). We acknowledge that through digital media and the strategies employed to ensure visibility among the communities of interest, "journals can define the greater or lesser degree of success (in other words, dissemination) of the work that researchers disseminate through them.” (Jiménez Contreras, 1992, pp. 174-175)

In the past three decades, subjects associated with the national criteria for scientific journals published in Colombia have been studied. Particularly noteworthy are the first initiatives to evaluate serialized publications (Gómez, 1999) and the construction of a national indexing system (Charum, 2004). Similarly, the following issues have been examined: difficulties for the journals to be included in the most well-known systems for indexation and referencing (SIR) (Delgado, 2011); problems associated with editorial processes to ensure the quality of publications (Gómez, Anduckia, \& Rincón, 1998; Ramírez Martínez et al., 2012); and challenges to ensure periodicity and visibility (Charum et al., 2003; Delgado, 2011; Jiménez Medina \& González Hernández, 2013; Molina-Molina \& De-Moya-Anegón, 2013). There has even been discussion about the careers of university professors in terms of the "puntimetro" or score, as the main reason for publishing to obtain points that will give rise to salary raises/increases (Gómez-Morales, 2015).

These aspects have been determinants in the life of foreign language journals. For example, we made a documentary analysis of the evolution of the $H O W$ journal and a characterization of the profiles of its authors, topics of interest, concerns about academic writing, and the repercussions of new national policies with respect to opportunities for national academics so that their publications in journals such as that one will gain deserved recognition. A series of challenges concerning publishing policies and processes, which are intimately associated with current trends in the evaluation systems that govern the classifications of academic journals, was also identified (Cárdenas, 2016).

In Profile journal, we examined the guidance for primary and secondary school teachers to publish in it and their difficulties as writers (Cárdenas, 2003; Cárdenas \& Nieto, 2010); the problems observed by peer evaluators in manuscripts submitted for publication as well 
as their implications for both academic writing and for teacher education (Cárdenas, 2019a); and the experience of teachers at diverse educational levels who have published in the journal about the reasons that led them to submit their manuscripts, their experiences during the publication process, and the meaning they place on the publication of their articles in the journal (Cárdenas, 2014, 2020). Additionally, we describe and analyze the circumstances in which the journal came into existence, experiences of authors who have published in it, concerns regarding matters of indexation and classification inherent to the Colombian context, the nature of the knowledge circulated in Profile and the challenges for publication in a peripheral context (Cárdenas \& Rainey, 2018). In light of this panorama, it is now interesting to analyze two elements that facilitate the presence of English teachers in local journals: their research activity and academic writing.

\section{The English Teacher as Researcher and Author of Articles}

We conceive of the teacher as an education researcher and intellectual (according to the postulates of Giroux, 1988; Nieto, 2006). Independently of the academic communities to which they belong, teachers have a cultural capital (Bourdieu, 1987), an accumulation of knowledge that makes it possible for them to participate in the knowledge society through their engagement in research and the subsequent publication of their findings. To make this possible, it is necessary to open venues for scientific dissemination that enable plural participation by the teachers. Thus, we face the challenge of having journals that transcend the concept of knowledge production in hegemonic contexts, to recognize contributions that stem from peripheral scenarios.

Based on the recognition that research can be undertaken by English teachers, of the knowledge that can be produced and the possibility to publish from the periphery in order to reach diverse educational and geographical contexts, a dialog is fomented among local communities, as well as between the periphery and the center. Therefore, the teacher's involvement in the dialogue that surrounds research and publication enables a form of empowerment. We clarify here that we understand the term to empower as a legitimate act to give power and authority so that teachers can play a more active role in the decisions by educational institutions, to thereby give them greater control over their work, and a voice in their profession (Kincheloe, 2003; Noffke \& Somekh, 2009; Zeichner, 2010). Thus, the local contexts where teachers work and the impact of their actions can be transformed, by which we can clearly see an empowerment of the teacher as social agent.

\section{Academic Writing}

Academic writing occupies a central place in the process of construction, dissemination and legitimization of knowledge (Canagarajah, 2006). From this perspective, we recognize 


\section{Melba Libia Cárdenas}

that in the local journals of Colombia, a priority is placed on awareness of the meaning of the internationalization of TESOL and the goal of surmounting the dependency of the dominant academic circles. Canagarajah associates those advances with the transition of a modernist orientation to a postmodernist one in the discourses. In connection to this, we can assert that we are promoting changes in the forms of knowledge dissemination and paying more attention to the geographic location of research, authorship, types of articles, and research methods.

In the research line that refers to academic writing, we can mention works that characterize the publications by English teachers (Rainey, 2005) and experiences in the accompaniment of authors during writing processes for publishing in scientific journals (Cárdenas, 2003, 2014; Cárdenas \& Nieto, 2010; Cárdenas \& Rainey, 2018; Lillis, Magyar, \& Robinson-Pant, 2010; Pérez-Llantada, Plo, \& Ferguson, 2011; Smiles \& Short, 2006). However, the literature shows that neither the perceptions of the authors and of those who accompany them (evaluators and editors), nor the research on English teachers as researchers and writers, nor their relationships with the professional cycle, have occupied a predominant place. We find thematic gaps that justify our interest in the experiences and meaning(s) of the journals as to the personal and professional dimensions of the authors, and the editorial processes that mediate the editing of academic journals published in peripheral countries, committed to shedding light on the educational and research work of English-language teachers in their professional and scientific communities.

Nonetheless, in reference to our interest in publishing results of action and innovation research projects carried out by primary and secondary school teachers, we have explored the role of that research approach in study groups and in networking (Cárdenas \& Nieto, 2007, 2010; Cárdenas, Nieto, \& Del Campo, 2011). In those studies, and in the ones cited below, we find that the vision of the journals and the accompaniment for possible authors play a preponderant role in achieving the objectives and in self-esteem. We have thus dealt with authors' and evaluators' perceptions regarding English teachers' difficulties in publishing scientific articles in peripheral contexts (Cárdenas, 2019a). Evaluators and authors agree on two problematic areas: academic writing and the inclusion of relevant content, according to the structure of the type of article. Certain authors also point to the effect of personal and employment circumstances as regards time management, work systems, and lack of confidence to reach their goals.

Furthermore, and following the narrative research approach, life stories have made it possible to detect fingerprints from the first publications by some English teachers (Cárdenas, 2019b). The accounts provide an understanding of the complexity of writing for publication, of the challenges in becoming a teacher and researcher and how multiple and changing identities are created throughout our lives and professional cycles. Finally, we summarize the study of the reasons that led a group of English teachers to send their manuscripts to be 
published in Profile. The analysis was made from the perspective of the logic of scientificsocial reasoning in the authors' opinions, and it was found that

The most important reason was communicative logic because the link with the academic community is of interest. Similarly, and in relation to the instrumental reason, the participants recognize the effect of publication in a renowned journal: personal satisfaction, recognition by their academic peers and, in a few cases, incentives that can be obtained for their professional career, represented in the teaching hierarchy or salary. In turn, although in a lesser proportion, there are arguments associated with critical logic, which reflect the authors' commitment as agents devoted to educational change, knowledge generation and research in their professional field. (Cárdenas, 2020, p. 222)

In the studies that we have mentioned, as well as in academic fora in the ELT field, we observe interest in showing the work of teachers and, also, to problematize dominant discourses that seek to perpetuate dependency on hegemonic knowledge, and which insist that it be transmitted worldwide, so that we continue the tradition of applying everything that comes in from abroad, without greater recognition of the contributions of local academics. Also, and to the extent that there is progress towards publications totally online or in both printed and electronic versions, and without restrictions for consultation of complete texts, there is an ever-increasing questioning over the adoption of guidelines from the "center" for publishing management and evaluation. These are associated with postmodernist and poststructuralist visions that sustain their conception of journals as social agents and promoters of the construction of academic communities.

\section{The Role of Local Journals in the Decolonization of Knowledge}

We have said that the elements shown in Figure 1 are fundamental axes for the decolonization of knowledge through local journals. In addition to these serialized publications, there must exist a commitment by the faculty to enable those publications to maintain their periodicity. In this sense, the possibility for English teachers also to be perceived as writers depends, to a great extent, on their conceptions about the role writing academic articles plays in their profession. As previously stated, the journals not only enable dissemination of knowledge contributed by teachers; they also create a culture for the dissemination of their own collection of knowledge and writings while attracting academic and professional communities. Also, and although indirectly, journals can contribute towards incorporation of the knowledge they publish into the work of teaching and enable those who read them to have dialogues with the authors or cite them in future publications. The journals in turn have the possibility to decide upon their vision and adoption of the parameters (policies and indexing systems) that govern them. 


\section{Melba Libia Cárdenas}

The continuity in the publication of local ELT journals that we have cited is congruent with the proposals by Colombian sociologist Orlando Fals-Borda (1997), a promotor of participatory action research, who is recognized as having connected a developing country of the South with intellectuals from the world of education and captured the attention of university professors who attempt to rebuild educational research in the hope of greater social justice. He thus argued that it is possible to produce serious and responsible knowledge that can be gathered through group experiences and information sharing.

Some of Fals-Borda's proposals were subsequently gathered in the first "Manifiesto" sobre la autoestima y la creatividad en la ciencia colombiana ["Manifesto" on self-esteem and creativity in Colombian science] (Mora-Osejo \& Fals-Borda, 2002) and are widely disseminated in Colombian and European spheres. That document debates "the effects of Eurocentrism in the development and simultaneous widening of the gap between the countries of the North and South" (p. 6). He also refers to "the urgent need for all societies to make universal knowledge available, [of] knowledge contextualized with our singular and complex realities" (p. 7). The authors also comment on the role of the universities as agents of change, committed to those realities. They thus conclude by pointing out that "participative universities committed to the common good, particularly the urgencies of grassroots communities, are required...The participative universities must be core crucibles of the mechanisms for creation, accumulation, teaching and dissemination of knowledge" (p. 16).

In agreement with this perspective, and from the epistemologies of the South, we may infer that maintaining local ELT journals, despite the disadvantages they may have compared to those of the center, is a way to respond to the need to have

new production processes, appraisal of valid scientific and nonscientific knowledge, and new relationships with different types of knowledge, based on the practices of social classes and groups that have systematically suffered destruction, oppression and discrimination caused by capitalism, colonialism, and all naturalizations of inequality in which they have unfolded. (De Sousa Santos, 2011, p. 35)

Since the beginnings of modernity, scientific journals have played a fundamental role in the construction and consolidation of science as a social institution and of scientific communities while also serving as a mechanism for dissemination of the achievements of these communities. Maintaining a local publication, without losing sight of its vision, and while responding to institutional, national, and international requirements, leads us to a decolonization of knowledge. This is possible because local knowledge is valued, written by diverse teachers, and can be read through open access. Also, as opposed to practices to pay to publish or to read what is published in journals of the center, access is permitted to research products generally financed with public funds. 
Open access leads to democratization of knowledge and rejects its commercialization, a practice widely established in the "center". "In this sense, it involves generating and strengthening venues for scientific dissemination created by and for Latin America and the Caribbean. These, in turn, will bring about a process of decolonization of scientific knowledge" (Aguado-López \& Vargas Arbeláez, 2016, p. 86).

Our commitment therefore falls on two geographic settings: the local and the global. As stated by González (2012), the impact indicators refer exclusively to global impact and say little or nothing about local impact. In the same spirit, it can be affirmed that we are in a crossroad: "on one side, to carry out and disseminate research that responds to local needs, and on the other, to do research that would have universal meaning and impact on the academic communities of each discipline" (González, 2012, par. 4).

On the other hand, indicators to measure the quality of Colombian journals have led to the application of publishing policies that favor the members of certain communities, denominated as "academic elites" - university professors or research centers — and ignore base or grassroots professionals — non-university teachers. In doing so, they seek to emulate the powerful "cult" or "modern" countries that have achieved supremacy in scientific and technological production and dissemination, increasing even more the divisions between the production of hegemonic and peripheral knowledge (Pageau, 2010). Those circumstances are unique to "an epoch — the epoch of Eurocentric modernity - that attributes total priority to scientific knowledge and the practices directly derived from it: the technologies" (De Sousa Santos, 2016, p. 163). Ironically, access to technologies is not fairly distributed in social groups or in academic communities, nor is it equitable among university institutions where that knowledge is given precedence. However, as the author adds, "belief in scientific progress is a sufficiently strong hope to neutralize any fears about the limitations of current knowledge" (p. 163). Here the universities play an important role, because they generate knowledge and lead publications to contribute to the knowledge society.

Currently, the main challenge, among many others, stems from recognition of the contributions of others' and of one's own capacities. We may thus decide to explore scenarios to coordinate the knowledge possessed by one another (by each contributor/author). In this sense, Pageau (2010) argues that, while there are no definitive solutions, it is possible to establish associations of meaning between hegemonic and peripheral knowledge, through opening and inclusive and decentered production. In our case, the search for inclusion of different voices in local journals implies not falling into the extremes of rhetoric for supremacy of the local or a change simply to capture works by certain communities. On the contrary, and in line with proposals for decolonization of knowledge, a perspective of inclusion is proposed, so that the greatest number of English teachers' voices may, in circumstances of equality, express themselves through recognition of the knowledge they possess and the mediation to boost those who have less experience. 


\section{Conclusions and Implications}

Based on a review of the literature and of studies carried out in the spheres of the English teacher as researcher and author, of academic writing and publication of scientific journals, we have argued that it is possible to advance towards decolonization of knowledge through those publications. We recognize that the appraisal of the journals does not depend exclusively on the institutions where they are published or on those who publish in them, because journals have become "the symbolic capital, through legitimizing entities, such as Publindex, Colciencias, and have organized the quality of knowledge by categories, accepted by higher education institutions" (Jiménez Medina \& González Hernández, 2013, p. 189). However, the first challenge for ELT journals published in Colombia is, without ignoring the knowledge that originates in the contexts of the "center", to adopt submissions that, from their contexts of the South or of the periphery, contribute towards their area of specialty and society in general. In fact, some of our Colombian ELT journals include not only university academics, but also grassroots teachers and new authors, whose voices are generally absent from academic publications. However, we would have to examine the degree of appreciation of local work, for example, through rates of rejection of manuscripts that are submitted for evaluation, of locally published citations and of the mentions they receive in journals published in other countries.

Local ELT journals coincide in their interest in surmounting the cult of one single pattern, namely, of the hegemony of the Occidental science model, which perpetuates dependence on authors from the academies of the North, as a standardizing power for the dogma from select latitudes and which forces scientific journals to adhere strictly to the precepts of the dominant models in their management of journals. The large percentage of authors in the journals who work in Colombia or in Latin America shows the importance of representing a science from the South and for the South from the periphery; in other words, based on local realities, to contribute to communities with similar interests or problems and the preparation of diverse generations of writers. We thus require university professors who work a bit more on the creation of venues for communication. This is already occurring in Colombia, for example, in the above-mentioned local journals. It is fair to ask, however, if they all adopt the principles of fairness regarding contributions by authors from diverse educational contexts

42 and if they recognize the authors' characteristics, understand the nature of their writings and the possible guidance they require to fulfill the journals' own quality criteria.

The consolidation of local ELT journals has also enabled the training and professionalization of editors and evaluators, as well as the motivation of teacher researchers and teacher educators who have been acquiring experience in publishing and have become leaders in certain areas. This reality has facilitated the definition or construction of the self as an author, evaluator, and editor. It has also stemmed from the recognition of new forms 
of research, an activity that until recently was viewed as the exclusive territory of an elite of the professional community. Nonetheless, we recognize that it is necessary to work even more on academic writing and research starting from the earliest stages of teacher education.

We hope that the vision and mission of the journals that, as we understand them, coincide with the perspectives for decolonization of knowledge, will not succumb to pressure aimed at ensuring their national and international classification. From our own experience, we may affirm that maintaining the journals in concordance with this line of thinking implies being aware not only of the particularities of academic writing and publishing processes, but of providing alternatives for the accompaniment of teachers at diverse educational levels and geographical contexts.

\section{References}

Aguado-López, E., \& Rogel-Salazar, R. (2009). Las revistas multidisciplinarias como medios de exposición del trabajo en colaboración: CIENCIA ergo sum, 1999-2006. Ciencia Ergo Sum 16(2), iv-x. http:/ /248.redalyc.org/articulo.oa?id=10411360013

Aguado-López, E., \& Vargas Arbeláez, E. J. (2016). Reapropiación del conocimiento y descolonización: el acceso abierto como proceso de acción política del sur. Revista Colombiana de Sociología, 39(2), 69-88. https://doi.org/10.15446/rcs.v39n2.58966

Bourdieu, P. (1987). Los tres estados del capital cultural. Sociológica, 2(5), 11-17.

Canagarajah, A. (2006). TESOL at Forty: What are the issues? TESOL Quarterly, 40(1), 9-34. https:// doi.org/10.2307/40264509

Cárdenas, M. L. (2003). Teacher researchers as writers: A way to sharing findings. Colombian Applied Linguistics Journal, 5, 49-64.

Cárdenas, M. L. (2014). Publishing and academic writing: Experiences of authors who have published in PROFILE. Profile: Issues in Teachers' Professional Development, 16(2), 11-20.

Cárdenas, M. L. (2016). Challenges of the HOW Journal in spreading teachers' works in times of ranking pressures. HOW, 23(2), 35-57. https://doi.org/10.19183/how.23.2.333

Cárdenas, M. L. (2019a). Dificultades de docentes de inglés para publicar artículos científicos en contextos periféricos: percepciones de autores y evaluadores. Íkala, Revista de Lenguaje y Cultura, 24(1), 181-197. https://doi.org/10.17533/udea.ikala.v24n01a11

Cárdenas, M. L. (2019b). Huellas de la primera publicación en un docente de inglés: un relato de vida. Folios, 49, 161-175. https://doi.org/10.17227/folios.49-9403

Cárdenas, M. L. (2020). Razones de profesores de inglés para publicar en una revista y las lógicas del razonamiento sociocientífico. Revista Colombiana de Educación, 78, 207-228. https://doi. org $/ 10.17227 /$ rce.num78-7357 


\section{Melba Libia Cárdenas}

Cárdenas, M. L., \& Nieto Cruz, M. C. (2018b). Challenges in sustaining a peripheral journal. Profile: Issues in Teachers' Professional Development, 20(2), 9-14. https://doi.org/10.15446/profile. v20n2.71948

Cárdenas, M. L., \& Nieto, M. C. (2007, mayo). El papel de la investigación acción en el trabajo de grupos de estudio de docentes de inglés de educación básica y media del sector oficial. Simposio Internacional Investigación Acción y Educación en Contextos de Pobreza. Universidad de la Salle, Bogotá.

Cárdenas, M. L., \& Nieto, M. C. (2010). El trabajo en red de docentes de inglés. Universidad Nacional de Colombia.

Cárdenas, M. L., \& Nieto, M. C. (2017). Resisting exclusion from core indexing systems. Profile: Issues in Teachers' Professional Development, 19(2), 7-11. https://doi.org/10.15446/profile. v19n2.64604

Cárdenas, M. L., \& Nieto, M. C. (2018a). Bibliometric indicators and their accurate use in the ranking of Colombian journals. Profile: Issues in Teachers' Professional Development, 20(1), 7-12. https://doi.org/10.15446/profile.v20n1.68848

Cárdenas, M. L., \& Nieto Cruz, M. C. (2018b). Challenges in sustaining a peripheral journal. Profile: Issues in Teachers' Professional Development, 20(2), 9-14. https://doi.org/10.15446/profile. v20n2.71948

Cárdenas, M. L., \& Rainey, I. (2018). Publishing from the ELT periphery: The Profile journal experience in Colombia. In M. J. Curry \& T. Lillis (Eds.), Global academic publishing: Policies, perspectives, and pedagogies (pp. 151-165). Multilingual Matters.

Cárdenas, M. L., Nieto, M. C., \& Del Campo, R. M. (2011). El programa de desarrollo profesional docente PROFILE: experiencias, reflexiones e implicaciones para el contexto colombiano. In J. A. Bastidas \& G. Muñoz Ibarra (Eds.), Fundamentos para el desarrollo profesional de los profesores de inglés (pp. 135-167). Universidad de Nariño.

Charum, J. (2004). La construcción de un sistema nacional de indexación: El caso de Publindex. Convergencia, 11(35), 293-309.

Charum, J., Murcia, C., Usgame, D., Silva, A., Barbosa, C., \& Rodríguez, S. (2003). La búsqueda de la visibilidad a través de la calidad: el reto del editor. ICFES.

Colciencias (2016b). Política nacional para mejorar el impacto de las publicaciones científicas nacionales (Documento No 1601). Autor.

De Sousa Santos, B. (2011). Epistemologías del sur. Utopía y praxis latinoamericana, 16(54), 17-39.

De Sousa Santos, B. (2016). La incertidumbre: Entre el miedo y la esperanza. In P. Gentili \& N. Trotta (Eds.), América Latina: la democracia en la encrucijada (1ª ed., pp. 161-169). Editorial La Página.

Delgado, J. E. (2011). Journal publication in Chile, Colombia, and Venezuela: University responses to global, regional, and national pressures and trends [Unpublished doctoral dissertation]. University of Pittsburgh. 
Fals-Borda, O. (1997). Participatory action research in Colombia: Some personal feelings. In R. McTaggart (Ed.), Participatory action research: International contexts and consequences (pp. 107-112). State University of New York Press.

Giroux, H. (1988). Teachers as intellectuals. Bergin \& Garvey Publishers.

Gómez, Y. J. (1999). A propósito de un ejercicio de evaluación de publicaciones seriadas científicas. In A. M. Cetto \& O. Alonso (Comps.), Revistas Científicas en América Latina - Scientific Journals in Latin America (pp. 375-390). International Council of Scientific Unions, Universidad Nacional Autónoma de México, Consejo Nacional de Ciencia y Tecnología, Fondo de Cultura Económica.

Gómez, Y. J., Anduckia, J. C., \& Rincón, N. (1998). Publicaciones seriadas científicas colombianas. Interciencia, 23(4), 208-217.

Gómez-Morales, Y. J. (2015). Usos y abusos de la bibliometría. Revista Colombiana de Antropología, 51(1), 291-307.

González, F. (2012, abril 11). Sobre el impacto de las publicaciones científicas. Boletín de la DIB, Año 3, No. 105. Universidad Nacional de Colombia.

Hicks, D., Wouters, P., Waltman, L., de Rijcke, S., \& Rafols, I. (2015). El manifiesto de Leiden sobre indicadores de investigación. Revista iberoamericana de ciencia tecnología y sociedad, 10(29), 275-280.

Jiménez Contreras, E. (1992). Las revistas científicas: el centro y la periferia. Revista Española de Documentación Cientifica, 15(2), 174.

Jiménez Medina, J. A., \& González Hernández, D. L. (2013). Cambios de paradigma de la divulgación del conocimiento en la educación superior en Colombia: Crisis desde el campo editorial universitario. Hallazgos, 10(20), 171-191.

Kincheloe, J. L. (2003). Teachers as researchers: Qualitative inquiry as a path to empowerment. Routledge Falmer.

Leon-Sarmiento, F., Bayona-Prieto, J., Bayona, E., \& León, M. (2005). Colciencias e inconciencias con los científicos colombianos: de la Edad de Piedra al factor de impacto. Revista de Salud Pública, 7(2), 227-235.

Lillis, T., Magyar, A., \& Robinson-Pant, A. (2010). An international journal's attempts to address inequalities in academic publishing: Developing a writing for publication programme. Compare: A Journal of Comparative and International Education, 40(6), 781-800.

Londoño, G. F. (2006). Factor de impacto. Revista Universidad EAFIT, 42(141), 5-8.

Minciencias (2020). Convocatoria para indexación de revistas cientificas colombianas especializadas - Publindex 2020. Ministerio de Ciencia, Tecnología e Innovación. https://minciencias.gov.co/convocatorias/fortalecimiento-capacidades-para-la-generacion-conocimiento/convocatoria-para

Molina-Molina, S., \& De-Moya-Anegón, F. (2013). Política nacional y visibilidad internacional: El caso colombiano. El Profesional de la Información, 22(6), 529-536. https://doi.org/10.3145/ epi.2013.nov.05 


\section{Melba Libia Cárdenas}

Mora-Osejo, L. E., \& Fals-Borda, O. (2002). La superación del eurocentrismo: Enriquecimiento del saber sistémico y endógeno sobre nuestro contexto tropical. Academia Colombiana de Ciencias Exactas y Naturales.

Nieto, S. (2006). Razones del profesorado para seguir con entusiasmo. Octaedro.

Noffke, S., \& Somekh, B. (Eds.) (2009). The Sage handbook of educational action research. Sage Publications.

Pageau, C. (2010). Producción de saberes hegemónicos y periféricos: hacia una apertura del horizonte epistemológico. Tinkuy, 12(mayo), 181-197. http://www.mineducacion.gov.co/ cvn/1665/articles-254919_archivo_pdf.pdf

Patalano, M. (2005). Las publicaciones del campo científico: Las revistas académicas de América latina. Anales de Documentación, 8, 217-235. http://revistas.um.es/analesdoc/article/view/145

Pérez-Llantada, C., Plo, R., \& Ferguson, G. R. (2011). "You don't say what you know, only what you can": The perceptions and practices of senior Spanish academics regarding research dissemination in English. English for Specific Purposes, 30(1), 18-30. https://doi.org/10.1016/j. esp.2010.05.001

Rainey, I. (2005). EFL teachers' research and mainstream TESOL: Ships passing in the night? Profile: Issues in Teachers' Professional Development, 6(1), 7-21.

Ramírez Martínez, D. C., Martínez Ruiz, L. C., \& Castellanos Domínguez, O. F. (2012). Divulgación y difusión del conocimiento: las revistas cientificas. Universidad Nacional de Colombia.

Smiles, T. L., \& Short, K. G. (2006). Transforming teacher voice through writing for publication. Teacher Education Quarterly, 33(3), 133-147.

Zeichner, K. M. (2010). La formación del profesorado y la lucha por la justicia social. Morata. 